\title{
5 \\ Fighting Soap: The Postwar Years
}

How radio has enlarged the horizon of the woman at home is one of the talking points Dame Enid Lyons has developed since she became an A.B.C. Commissioner in 1951. Now a woman can do two things at once: cultivate her mind and do her housework. ${ }^{1}$

In July 1951, Dame Enid Lyons was appointed as a commissioner of the Australian Broadcasting Commission (ABC), replacing Western Australian Labor activist Ivy Kent. This was a fitting post-parliamentary career for a woman who had long been associated with broadcasting. Lyons's appointment was greeted warmly by senior $\mathrm{ABC}$ management and the public at large, although the Australian Labor Party attacked it as a 'case of political patronage' that demonstrated the Menzies government's intention to make the $\mathrm{ABC}$ a 'propaganda medium of the Liberal and Country Parties'. ${ }^{2} \mathrm{ABC}$ Chairman Richard Boyer wrote to her following the appointment to express his delight that she had agreed to accept a position as a member of the commission. ${ }^{3}$ He believed that her 'career and stature in the public mind' meant that 'all of women's interests' would be satisfied by her appointment and, moreover, the regard with which she was held by the population would increase 'public confidence'

1 'Dame Enid Lyons: ABC Commissioner', ABC Weekly, 27 March 1954, 20.

2 'Dame Enid Lyons Appointed to A.B.C.', Canberra Times, 14 July 1951, 4; Charles Moses to Dame Enid Lyons, 13 July 1951, MS 4852, Papers of Dame Enid Muriel Lyons, Box 8, National Library of Australia, Canberra.

3 Richard Boyer to Dame Enid Lyons, 13 July 1951, MS 4852, Papers of Dame Enid Muriel Lyons, Box 8, National Library of Australia, Canberra; 'Dame Enid Lyons Appointed to A.B.C'. 
in the ABC's personnel. ${ }^{4}$ As a leading woman broadcaster, Lyons had done much to establish radio as a platform for women to contribute to public discourse, and now she could use her skills and status to shape the direction of the national broadcaster. As noted in the above quotation from the $A B C$ Weekly, Lyons used the position to continue to promote the interests of women in broadcasting and emphasise the impact of the medium on women's lives and ambitions. However, despite her advocacy of the importance of radio to women's status, the postwar period saw the decline of talk-based women's sessions as a key platform for the advancement of women's equality. Lyons represented an older generation of women who had come into their own through broadcasting during the crisis years of the 1930s and 1940s — a perspective of decreasing relevance in the era of aspirational postwar prosperity.

The 1940s and 1950s have been described as the 'golden age' of Australian radio due to the proliferation of Australian serial dramas and light entertainment on the air, especially on commercial stations. ${ }^{5}$ In many cases, these programs displaced talk-based women's sessions in their traditional mid-morning and mid-afternoon timeslots. The $\mathrm{ABC}$, however, continued to broadcast women's sessions that tackled complex social, cultural and political issues. Although the listening figures for these sessions were relatively low and they tended to attract educated middleclass women, they do provide evidence of the role that the $A B C$ played (and saw itself playing) in encouraging women to be active and engaged citizens in the postwar world.

Ida Elizabeth Jenkins compered the ABC national women's session in the 1950s and discussed a range of social and political issues on her program. Larger audiences were found in Western Australia, where Catherine King's state $\mathrm{ABC}$ women's session attracted a loyal following. The West also bucked the trend in terms of commercial women's programming, as Irene Greenwood additionally ran a session on Perth's Whitford's network during this period that included an array of social and political content alongside well-cloaked advertising. These women continued to view broadcasting as a platform from which they could exercise leadership to combat what they saw as the threat of the increasing popularity of serial dramas to women's status as engaged citizens. They believed that radio was

$4 \quad$ Boyer to Lyons, 13 July 1951.

5 Richard Lane, The Golden Age of Australian Radio Drama, 1923-1960: A History through Biography (Melbourne: Melbourne University Press, 1994). 
still a medium that could empower women and they used their programs to promote their ideal of the postwar woman citizen. However, their efforts were met with mixed success. While they were able to claim space on the airwaves and broadcast programs that emphasised engaged citizenship, and while there is evidence that some listeners at least were receptive to their efforts, the increasing airtime given to serial dramas during daytime hours eroded the traditional audience for women's sessions and marked a shift away from this style of talk-based programming.

\section{The Golden Age?}

Radio serials were broadcast in Australia from the 1930s, including the popular Australian serial Dad and Dave that featured on the ABC from 1937. ${ }^{6}$ Big Sister, the first nationally sponsored women's serial to be broadcast in Australia, went to air in 1942, and a large number of plays were broadcast on both the $\mathrm{ABC}$ and the commercial stations during the 1940s. Radio drama was also produced to promote war bonds and increase morale and patriotic sentiment during World War II. ${ }^{7}$ Further, as David Goodman and Susan Smulyan have shown, American serial scripts began to be lightly rewritten and completely revoiced in Australia during the war, when transcription discs from non-sterling areas faced import restrictions. This resulted in a growing radio serial industry in Australia, as local actors and production staff produced local versions based on American scripts, including the popular serials When a Girl Marries, Portia Faces Life and Doctor Paul. ${ }^{8}$

There was a 'frenzy' of production of radio serials in the late 1940s and early 1950s, which transformed morning and afternoon schedules on commercial radio. ${ }^{9}$ The rise of these programs caused some controversy due to their subject matter and perceived vapidity, and this continued over several decades. The voices of serial stars were also singled out for criticism, usually in terms of their overwrought acting or the sameness,

6 K. S. Inglis, This is the ABC: The Australian Broadcasting Commission, 1932-1983 (Carlton, Vic.: Melbourne University Press, 1983), 55.

7 Lane, The Golden Age of Australian Radio Drama, 201-02.

8 David Goodman and Susan Smulyan, 'Portia Faces the World: Re-Writing and Re-Voicing American Radio for an International Market', in Radio's New Wave: Global Sound in the Digital Era, ed. Jason Loviglio and Michele Hilmes (New York \& London: Routledge, 2013), 163-79.

9 Bridget Griffen-Foley, Changing Stations: The Story of Australian Commercial Radio (Sydney: UNSW Press, 2009), 234-35. 
which is apparent when listening to a number of these programs. ${ }^{10}$ Australian serials were still often Australianised versions of American scripts, continuing the trend that had begun during the war years. ${ }^{11}$ The talk-based women's sessions that had dominated in the 1930s and early 1940 s were increasingly replaced by soap operas, which proved lucrative for the commercial stations. The sessions that had provided women with a platform to contribute to public discourse were disappearing in favour of radio dramas that treated women as listener-consumers who took in advertising messages along with addictive storylines, rather than listenercitizens who wanted to engage with social and political commentary.

Serial dramas even became a common fixture on the ABC. From 1944 it began airing Gwen Meredith's serial The Lawsons, a drama that followed the lives of a tight-knit community in regional Victoria. In 1949, The Lawsons turned into Blue Hills, and this program became one of the most successful radio serials in Australia, running until 1976 and attracting huge audiences. The program was appealing to audiences for its rural setting, which tapped into romanticised notions of the country that were central to Australian national identity, and because its storylines were centred on popular romance. ${ }^{12}$ Yet, while the $\mathrm{ABC}$ did broadcast popular serial dramas like Blue Hills, it should be stressed that the national broadcaster did not wish to emulate its commercial rivals and program back-to-back soap operas during the morning-it still recognised the value of the talk-based women's session.

Soap operas became a source of anxiety for governments and many cultural commentators who believed that they had a negative influence on engaged listener-citizens. This was the case in many countries around the world, including the United States, where their 'moribund' content made them a subject of national concern. ${ }^{13}$ As such, the remaining talk-based women's sessions consciously positioned themselves against soap operas, and the organisers of these sessions often wanted to provide an intellectual alternative to what they viewed as a vapid form of programming. This was especially so for the $\mathrm{ABC}$, which had a philosophy similar to the BBC's citizen-shaping ethos. There was a 'dual system' for women in

10 Phil O’Brien, 'Women's Voices', Listener In, 22 January 1955, 29.

11 Goodman and Smulyan, 'Portia Faces the World', 170.

12 Michelle Arrow, "The Most Sickening Piece of Snobbery I Have Ever Heard": Race, Radio Listening, and the "Aboriginal Question" in Blue Hills', Australian Historical Studies 139, no. 38 (2007): $244-48$.

13 Michelle Hilmes, Radio Voices (Minneapolis: University of Minnesota Press, 1997), 155. 
the $A B C$ hierarchy; while the majority were corralled into supposedly feminine support jobs, there was a small minority who were valued by the commission as 'exceptional contributors' and were given greater opportunities to advance their careers and influence $\mathrm{ABC}$ programming and policy. ${ }^{14}$ These exceptional women were generally highly educated, middle class and, notably:

Conceptualised themselves as citizens rather than feminists ... they saw themselves as capable and culturally superior, and felt confident to speak for others and make judgments about what was best for society. ${ }^{15}$

The $\mathrm{ABC}$ was the 'preferred venue for their activism' as its major role was to educate its listeners. ${ }^{16}$

The $\mathrm{ABC}$ women's sessions were a forum for postwar housewives to air their frustrations with domesticity. The ABC believed that the increased ownership of modern domestic appliances meant that housewives now had more free time, which women were using to listen to serials. While these programs satiated their boredom, they did not help their development as citizens. To address this perceived problem, the $\mathrm{ABC}$ sought to air programming that encouraged women to make productive use of their time by engaging with social and political issues and contributing to public discourse. According to Lesley Johnson and Justine Lloyd, radio, and especially the $\mathrm{ABC}$ :

Was the medium that would make women full 'citizens' in a democratic nation by taking them out of their own world and relating their personal domestic problems to those of others. ${ }^{17}$

By recognising that women's experience of domesticity could be improved by engaging with public affairs, the $\mathrm{ABC}$ also intimated that it was possible for women to step out of the private domestic role. ${ }^{18}$

14 Kylie Andrews, 'Don't Tell them I Can Type: Negotiating Women's Work in Production in the Post-War ABC', Media International Australia 161 (2016): 2.

15 Ibid., 4.

16 Ibid.

17 Lesley Johnson and Justine Lloyd, Sentenced to Everyday Life: Feminism and the Housewife (Oxford and New York: Berg, 2004), 130.

18 Ibid., 131-41. 


\section{The Western Australian ABC Women's Session}

Catherine King's Western Australian $A B C$ Women's Session began in the final months of World War II and would prove to be one of the most popular women's sessions of the postwar era. When searching for a host for the session, ABC Perth Manager Conrad Charlton argued that she 'should be chosen both for her cultural ability and for her place in the respect of female sorority', and put forward Catherine King for the role. ${ }^{19}$ He noted that King was 'very well informed in all women's affairs, is head of the Kindergarten Union in this state' and also possessed 'good administrative ability'. ${ }^{20}$ King had been involved with broadcasting for several years, first as a children's book reviewer for the ABC Women's Session in the 1930s and later as an organiser of the successful children's program Kindergarten of the Air in the early 1940s. ${ }^{21}$ She was also the daughter of Sir Walter Murdoch, an academic at the University of Western Australia and a leading public intellectual.

The session premiered on 4 September 1944. The Broadcaster enthusiastically reported on the new program, and noted that, from the outset, it would be focused on intellectual engagement: 'It will be a session which will provide not only knowledge and news but will present ideas of a sufficiently controversial nature to set listeners thinking. ${ }^{22}$ The magazine reported that the session would include talks on science, women in careers, infant health, women's organisations and literature. ${ }^{23}$ The announcement of the new session generated a very positive response from prospective listeners. Several women wrote letters to the Broadcaster to express their gratitude that the Western Australian $A B C$ Women's Session was being reinstated, noting that 'good interesting talks will fill a longfelt want among women listeners'. ${ }^{24}$ This relief was keenly felt in the context of wartime Western Australia, when print restrictions, petrol rationing and long distances left many women isolated and feeling cut-off from the

19 Conrad Charlton to Keith Barry, 24 May 1944, Talks - Mrs Catherine King - Women's Session WA [Box 38], SP1558/2, 650, National Archives of Australia (hereafter NAA).

20 Conrad Charlton to Keith Barry, 9 June 1944, Talks - Mrs Catherine King - Women's Session WA [Box 38], SP1558/2, 650, NAA.

21 Julie Lewis, On Air: The Story of Catherine King and the ABC Women's Session (Fremantle: Fremantle Arts Centre Press, 1979), 17-24.

22 'ABC Women's Session: Begins on Monday', Broadcaster, 30 August 1944, 3.

23 Ibid.

24 'Mrs. M. J.', 'Women’s Session Welcome’, Broadcaster, 13 September 1944, 8. 
outside world. The program was welcome listening during the end of the war and encouraged women to take an active role in their communities and local government in the postwar future. ${ }^{25}$

In August 1945, one year after the program's launch, the Broadcaster reflected on the impact of the session, observing that the core of the program's output was at least 10 talks per week on a variety of subjects. The intellectual stimulation that women had received through the session was a major reason for its popularity:

A very large number of Australian women are keen to improve their knowledge, particularly where fuller understanding of current developments will assist them in doing the best they can for their homes and families. ${ }^{26}$

The positive response to the intelligent content of the program continued throughout the late 1940s. In January 1948, for example, the $A B C$ Weekly reported that King had:

Built up a session that is not only popular-evidenced by a large correspondence from listeners - but has made it an intelligent and educational feature, covering a comprehensive range of subjects. ${ }^{27}$

These subjects included education, science, girls' careers, local government, women in international affairs, books, news commentary, marriage and parenting. ${ }^{28}$

One of the most popular series of talks on King's program was titled 'Life is an Art', which featured Reverend Brian MacDonald reading a series of talk scripts about faith and life originally written for the BBC. King was a committed Anglican who deeply considered the philosophy of life and believed that her listeners were also seeking spiritual and philosophical nourishment. ${ }^{29}$ Reporting on this series of talks, the Broadcaster asked whether women were 'natural highbrows' and if there was an 'unexpected fund of seriousness in the women of Western Australia':

25 'A.B.C. Women's Session: Wide Range of Subjects', Broadcaster, 21 March 1945, 6.

26 'The Feminine Angle', Broadcaster, 29 August 1945, 6.

27 'Her Women's Session Covers a Wide Field', $A B C$ Weekly, 10 January 1948, 15.

28 Ibid.

29 Lewis, On Air, 57. 
There used to be a theory that women wanted to hear about things which would help them run their houses. So they do-but they can get that from friends and neighbours. In addition what they want from radio (and what they continually assert that they want) is talks which will widen their world ... And so the talks for which they write in continually to the ABC women's session are those which deal with education, those which help them in their choice of books, those which tell them of recent discoveries in science in many different forms, those which give a current comment on events of importance in community life, those which discuss adolescence ... life in other countries, talks on politics and local government, talks by visitors from overseas, and, perhaps most popular of all, those which deal with life itself. ${ }^{30}$

This 'seriousness' may have been unexpected in the eyes of the Broadcaster's editors, but it can be seen as a continuation of earlier trends in women's programming. What is perhaps different is that women's interest in 'serious' issues was more openly recognised and talked about in broadcast media and by the $\mathrm{ABC}$ in particular. Keen to distance itself from vapid commercial soap operas, the $\mathrm{ABC}$ appears to have placed greater importance on its women's sessions during the 1940s and 1950s as a vital method of citizenship education for women. This was due to both its own self-conception as a bastion of cultural education and the tireless advocacy of women like King, who used her position to organise talks that focused on a range of social issues.

King's fierce belief in using radio to engage women as active citizens was apparent in her response to a script called 'Adventures in Fashion' sent to her by ABC Talks Director B. H. Molesworth. King took exception to some aspects of the script, especially a statement that buying 'a new spring hat' was the female equivalent to male adventure:

You see, the whole trend of our session is to prove that life, whether in war or peace, is every bit as full of exciting possibilities, whether in local government or science, or art, or literature, or education, or exploration, as life for men. And while I'm far from being a feminist, or an exponent of ideas of the equality of the sexes, it would certainly put this session in a queer position if we were suddenly to suggest that to men, belongs the high adventure, for women, the dashing accessory to her wardrobe. ${ }^{31}$

30 'Are Women Natural Highbrows?', Broadcaster, 4 April 1945, 6.

31 Catherine King to B. H. Molesworth, 14 October 1946, Talks - Mrs Catherine King - Women's Session WA [Box 38], SP1558/2, 650, NAA. 
Here King disavowed the feminist label, arguing that she was not an advocate for women's equality. However, at the same time, she was passionate about expanding the horizons of her listeners' lives, stoking their interest in a wide range of topics and encouraging them to think of ways they could participate in society, politics and the paid workforce outside their roles of wife, mother and homemaker. She therefore practised feminism, even if she did not identify as a feminist.

King discussed her experiences and motives for her long broadcasting career in an interview on $\mathrm{ABC}$ radio in Perth in 1982, and admitted that she did not like television, as radio was all she believed in. She argued that it was possible to be more honest and interesting on radio as it was an intimate medium through which you could talk person to person, and this intimacy activated her. Her session established that women were interested in a wide range of subjects and that women broadcasters could craft intellectually engaging sessions. ${ }^{32}$ She used her position to improve the lives of women and integrate them into the public sphere, and the longevity of her session and the legacy it left in Western Australia indicate that her approach was a popular one-more so than the $\mathrm{ABC}$ national women's sessions.

\section{The ABC National Women's Sessions}

With the exception of the Western Australian session, the separate statebased women's sessions were replaced by a Sydney-based national session in 1946, organised and compered by Clare Mitchell. This iteration did not last long as Mitchell resigned in late 1947, complaining that what she had been asked to do was 'wishy-washy'. ${ }^{33}$ Following Mitchell's resignation, $\mathrm{ABC}$ management undertook a review into the women's session and made suggestions for how to improve it. The format in which the 'Compere spoke herself and then introduced three or four other speakers' was 'now outmoded'; they suggested instead that the program be recast as a 20-minute magazine with a daily serial and content 'more slanted on things of special interest to women'. ${ }^{34}$ Female listeners had provided

32 Catherine King, Interviewed by Des Guilfoyle, July 1982, OH 572, State Library of Western Australia, Perth.

33 Inglis, This is the $A B C, 169$.

34 Keith Barry to Charles Moses, 20 January 1948, National Women's Session [Box 36], SP724/1, $13 / 3 / 4$, NAA. 
feedback that 'the magazine should include on at least one day a week, an item which provided more solid mental food, not depending on topicality or domestic interest'. ${ }^{35}$ In April 1946, a listener named D. K. Horton wrote to the $A B C$ Weekly to outline what she believed women preferred in their radio sessions. She nominated varied material: information on childcare, health and cooking, chats about beauty and fashion, and book reviews and short stories. Above all, however, the session required a competent presenter to run it:

She needs wide culture, an interest in almost everything, a knack of contacting fascinating personalities in art, social activities and science, and presenting these either by interview or through their writings to the audience. She must avoid like poison the schoolmistress or impersonal approach-women have to be talked down to, and even good material loses its appeal if a reader is aloof and uninterested, except in her own powers of elocution. ${ }^{36}$

Horton wrote again in September 1947 to complain about Mitchell's session, which she argued had the 'taint of the lecture hall' about it and was not 'friendly and personal' enough. ${ }^{37}$ According to Horton, women's sessions needed both engaging content and an engaging compere to run them.

Sheila Hunt took over as compere from April 1948 and oversaw the change of the session to a magazine format. At that time, she was the only woman announcer at the ABC's Sydney studio. In an interview with the $A B C$ Weekly, she compared the ABC unfavourably with the BBC, which she noted had a much larger proportion of female announcers. ${ }^{38}$ The BBC had also introduced its own women's program, Woman's Hour, to increase women's engagement with social and political issues in the postwar era. ${ }^{39}$

Interestingly, in this interview Hunt recognised the importance of radio as a medium that normalised the sound of women's voices in the public sphere: 'I do think women have something to offer on the air, if it is only

35 Extract from Minutes of Conference of National Talks Advisory Committee Held at A.B.C. Building, 171 William Street, Sydney, from Tuesday to Thursday, 17-19 August 1948, 1085/47, National Women's Session [Box 36], SP724/1, 13/3/4, NAA.

36 D. K. Horton, 'What Women Prefer', $A B C$ Weekly, 20 April 1946, 19.

37 D. K. Horton, 'Women's Session', ABC Weekly, 20 September 1947, 26.

38 'Young A.B.C. Announcer Now Comperes the Women's Session', ABC Weekly, 13 March 1948, 18.

39 Kristin Skoog, 'Neither Worker nor Housewife but Citizen: BBC's Woman's Hour 1946-1955', Women's History Review 26, no. 6 (2017): 2. 
a change from men's voices'. ${ }^{40}$ When the new format was launched on 5 April, Molesworth said that the $\mathrm{ABC}$ expected a 'stronger reaction' from Australian women to the 'brighter, quicker, more definite and immediate' session, most likely in the form of increased listener figures. ${ }^{41}$ Some listeners did appreciate the session, and wrote in to the $A B C$ Weekly to say so. One listener, who appreciated the variety of interesting subjects and people on the program, wrote that she was happy that the $A B C$ realised that 'the modern, educated housewife is interested in many things apart from children's complaints and Monday's washing. ${ }^{42}$ Another wrote that all 'the interesting talks on various subjects are enlightening' ${ }^{43}$ Others, however, disliked the new format. Horton, ever displeased, described it as 'snippety, jerky, and far too short'. ${ }^{44}$

Despite the new format, the Women's Magazine still struggled to attract listeners. In 1950, it averaged just 1 per cent of homes in Sydney, Melbourne, Adelaide and Newcastle, and 2 per cent in Brisbane. ${ }^{45} \mathrm{ABC}$ reports of the session's failures noted that it was a 'closely packed 20 minutes of almost unbroken speech, covering a variety of subjects unrelated except that they could all be of interest to some women'. ${ }^{46}$ The session sounded as if a 'stock' women's magazine was being read out - but this suffered from the lack of visuals present in a print magazine. ${ }^{47}$ The format lacked coherence and required too much concentration, and women seemed to prefer the light entertainment offered by serials on the commercial stations. Many other criticisms were levelled at the show, including too many guest speakers who were not good broadcasters, too many subjects of narrow interest, too much focus on 'dream stuff' that was out of the reach of 'Mrs Suburbia' and the lack of a personable compere. ${ }^{48}$

The low listener figures were not helped by the contradictory ideas put forward by ABC management. In a report from June 1951, Controller of Programs Keith Barry argued that the session should be for the 'average'

40 Ibid.

41 'A.B.C.'s New Women's Magazine of the Air on April 5', ABC Weekly, 3 April 1948, 18.

42 Alice Howard, 'Women's Session', $A B C$ Weekly, 24 April 1948, 2.

43 Hilda Voysey, 'Women's Session', $A B C$ Weekly, 23 October 1948, 2.

44 D. K. Horton, 'Women's Session', $A B C$ Weekly, 18 September 1948, 29.

45 Listener Research 27 March 1951, National Women's Session [Box 36], SP724/1, 13/3/4, NAA.

46 Elizabeth Campbell, 29 March 1951, National Women's Session [Box 36], SP724/1, 13/3/4, NAA.

47 J. J. Donnelly, 29 March 1951, National Women's Session [Box 36], SP724/1, 13/3/4, NAA.

48 Ibid.; Elizabeth Campbell, 29 March 1951, National Women's Session [Box 36], SP724/1, 13/3/4, NAA. 
woman and suggested several subjects that should make up the core of its repertoire: gardening, cooking, clothing, children, celebrities, home jobs, health, travel, book reviews and, notably, careers. Subjects that should be covered occasionally included foreign affairs, handicrafts and sport. ${ }^{49}$ However, in the final report submitted the following week, Molesworth argued that the $\mathrm{ABC}$ should not 'aim at the audience who listen to the serials on the commercials' but instead should try to 'serve the interests of the normally intelligent woman who sees beyond the mundane chores of domestic life and the naïve approach of the popular serial'. ${ }^{50}$

On the one hand, the $\mathrm{ABC}$ was concerned about appealing to the 'average' woman and not talking about things that were out of reach to the ordinary housewife. On the other, they viewed their audience as women of 'intelligence' who did not lower themselves to listening to serials. This supposed tension between the 'average housewife' and the 'intelligent woman' demonstrated the difficulties that the $\mathrm{ABC}$ experienced in attracting a larger audience for its national women's session; without a clear vision of who their audience was, the program struggled to produce coherent content and attract listeners, especially in competition with the popular format of serial dramas on the commercial stations. Audience intelligence had long been of concern to governments, radio executives and cultural commentators in many parts of the world. During the interwar years in the United States, for instance, there was significant concern 'about whether the mass of people were actually intelligent enough to undertake the tasks of radio listening responsibly'. ${ }^{51}$ Although it is unlikely that this tension between the 'average' and the 'intelligent' woman was new, it does appear to have been a significant concern that both shaped and inhibited the ABC's approach to women's programming in the postwar era.

Following their discussion of these reports, the $\mathrm{ABC}$ decided to renew the session with changes, and Ida Elizabeth Jenkins was hired as the compere. Jenkins was already a well-known and well-loved voice on the $\mathrm{ABC}$, having hosted the popular ABC children's session in the $1940 \mathrm{~s} .{ }^{52}$

49 Keith Barry to B. H. Molesworth, 18 June 1951, National Women's Session [Box 36], SP724/1, 13/3/4, NAA.

50 B. H. Molesworth, 'Women's Magazine: Summary of Comments Received', 22 June 1951, National Women's Session [Box 36], SP724/1, 13/3/4, NAA.

51 David Goodman, Radio's Civic Ambition: American Broadcasting and Democracy in the 1930s (Oxford: Oxford University Press, 2011), 253.

52 'Ida Jenkins in Charge of New Women's Session', ABC Weekly, 10 November 1951, 7. 
Reporting on her appointment in November 1951, the $A B C$ Weekly noted that the session would 'be geared to the woman in the home, whose daily routine tends to be less high-powered than that of the city worker'. ${ }^{53}$ This did not mean that the material would be dumbed downindeed, Jenkins intended 'to widen the scope of the session, with as large a panel of speakers as possible' and said that she would do 'anything to lift the housewife out of her sink'. ${ }^{54}$ The children's session connection was emphasised, as Jenkins herself noted that many of her former listeners would now be wives and mothers who would 'listen to me all over againfrom a new angle. ${ }^{55}$ There was some pushback against the rhetoric of housewife betterment, however. A listener complained to the $A B C$ Weekly that housewives found 'the superior attitude of many women who work for a living as irritating as it is amusing' and hoped that Jenkins would not condescend to her well-informed housewife listeners. ${ }^{56}$ The tension between the 'average' and 'intelligent' woman was again in play, as this listener chafed at what she viewed as the 'intelligent' compere talking down to the 'average' housewife. Housewives, this listener argued, were in fact already intelligent listeners who could engage on equal footing with the content presented by comperes such as Jenkins. This was a tension that Jenkins had to navigate in her role as compere; not only was $A B C$ management divided over what the best approach should be, but also her listeners had their own opinions on the issue.

The early sessions under Jenkins's stewardship were along the lines suggested in the ABC's report: Mondays were for talks on homemaking and travel, Tuesdays featured family advice and a book review, Wednesdays featured talks by a female doctor and an interview with the guest of the week, Thursdays had talks on cooking and childrearing, and Fridays featured talks on gardening and fashion. ${ }^{57}$ Providing competition to serials continued to be a focus of concern. It was observed in a report in October 1952 that, due to their afternoon serials, Sydney commercial station $2 \mathrm{UW}$ had built up its audience share from 2 per cent to 8 or

56 L. Hall-Jackson, 'Condescension Not Wanted', ABC Weekly, 24 November 1951, 2.

57 See for example: 'The Women's Session: Week Beginning 2nd December', National Women's Session [Box 36], SP724/1, 13/3/4, NAA. 
12 per cent, but that audiences for morning serials were double these figures - an indication of the significant popularity of soap operas and the uphill battle that talk-based women's sessions faced to win over listeners. ${ }^{58}$

Historians Lesley Johnson and Justine Lloyd have suggested that that the $\mathrm{ABC}$ national women's session increasingly focused on fashion and travel in the early 1950s, rather than social and political issues, as it was under significant pressure from other programs, especially soap operas. ${ }^{59}$ Yet, this argument neglects the influence of Jenkins, who very much saw her role as a leader to her audience and supplemented the program's domesticfocused content with commentary on myriad social issues. Jenkins's attitude towards women's role in society can be seen in a speech she gave to the Newcastle Business Men's Club in 1953 in which she argued that Australia was very much a 'man's country' that wasted the potential of its women by debarring them from public life once they got married. She argued that 'Australian women would be capable of work outside the home as well as in it'. ${ }^{60}$

By including her listeners' opinions and experiences in her session, Jenkins endeavoured to compensate for the loss of women's potential in public life. In 1953, she developed a social survey for married women so that she could gauge women's opinions on a range of subjects and discuss them on the air. ${ }^{61} \mathrm{~A}$ two-page written questionnaire was devised by the ABC's research division at her behest that asked women questions about jobs, housework, free time, relationships with their husbands and what could be done to help women prepare for marriage. The final question asked: 'If you were quite free to do whatever you wanted, what would you like to do?' ${ }^{\prime 2}$ This question recognised that it was possible for a woman to have ambitions beyond the domestic sphere, although she might still desire to be in the home. The survey was sent to a diverse sample of women from across Australia, including women in regional areas. ${ }^{63}$ Unfortunately, there is no record of the results of the survey and it is not clear what impact this research had, if any. However, the example demonstrates how

58 Keith Barry to Charles Moses, 23 October 1952, National Women's Session [Box 36], SP724/1, 13/3/4, NAA.

59 Johnson and Lloyd, Sentenced to Everyday Life, 141.

60 'Australia "Man's Country", Newcastle Morning Herald and Miners' Advocate, 3 September 1953, 5.

61 Nancy Sheehan to Keith Barry, 9 January 1953, National Women's Session [Box 36], SP724/1,

13/3/4, NAA.

62 'Social Survey for Married Women', National Women's Session [Box 36], SP724/1, 13/3/4, NAA.

63 Keith Barry to B. H. Molesworth, 19 January 1953, National Women's Session [Box 36], SP724/1, 13/3/4, NAA. 
Jenkins attempted to make the program of relevance to Australian women and that she wanted to include their own words and opinions on the program—not just her own.

Each week, listeners' letters on a given topic were read out by Jenkins and her guests, and Jenkins always ensured that equal weight was given to each side of a debate. The practice of reading listener letters incorporated the audience into the program more directly, and the readers did not comment on the letters but let them speak for themselves. Jenkins used letters as a device to discuss controversial issues on air by soliciting responses to a topic she had set. For instance, in November 1954 Jenkins broadcast listeners' letters on the topic of euthanasia. Most of the letter writers were staunchly opposed for religious or moral reasons. However, some supported it, such as a veterinarian who had been 'able to painlessly and permanently relieve the sufferings of many animals' and who did not see why humans could not also choose to end their own suffering, and a nurse who admitted that she had carried out treatment plans prescribed by doctors with the understanding that they would hasten the end of hopelessly incurable and agonised patients' ${ }^{64}$ The topic elicited a protest from pharmaceutical chemist Robert B. Billings who complained to ABC Chairman Richard Boyer that euthanasia was 'deliberate murder' that was 'opposed to God's teaching' and, as such, it was not appropriate to discuss or debate the topic on air. ${ }^{65}$ Boyer replied to Billings in early December, noting that the free discussion of viewpoints was crucial to robust public debate. However, Boyer referred Billings's complaint to the ABC Board. ${ }^{66}$ Jenkins's response to the criticism was to highlight the purpose of the national $A B C$ Women's Session as a forum for discussion of thorny social issues:

The 'Women's Session' is designed for an audience of intelligent adults, and the well reasoned, stimulating discussions we have had in the past of such subjects as Japanese Wives, Co-education, Racial Discrimination, assimilation of Migrants, etc., prove that a very big section of housewives wants more thought-provoking material from their radio than is supplied by the usual serials and soap-operas. ${ }^{67}$

64 'The Women's Session Conducted by Ida Elizabeth Jenkins', Script, 30 November 1954, National Women's Session [Box 36], SP724/1, 13/3/4, NAA.

65 Robert B. Billings to ABC Chairman, 30 November 1954, National Women's Session [Box 36], SP724/1, 13/3/4, NAA.

66 Richard Boyer to Robert B. Billings, 9 December 1954, National Women's Session [Box 36], SP724/1, 13/3/4, NAA.

67 B. H. Molesworth to Keith Barry, 15 December 1954, National Women's Session [Box 36], SP724/1, 13/3/4, NAA. 
Once again, the example of 'mind-numbing' soap operas was raised to justify the need for the women's session to discuss a wide range of stimulating and often difficult issues of public interest. Molesworth agreed: he did not see why euthanasia should be 'excluded from the controversial topics which we should be free to discuss' ${ }^{68}$ Indeed, one correspondent, a disabled war veteran, expressed in his submission to the debate that it was 'a very healthy sign when a subject like euthanasia can be discussed over the air, and particularly in a women's session'. ${ }^{69}$

Jenkins appears to have been a key drawcard for the audiences that tuned in to the session. For instance, a listener wrote to the $A B C$ Weekly in 1954 to express their approval of the 'interesting, informative, and delightfully refreshing' session, and of Jenkins' 'charming, well-modulated voice'. ${ }^{70}$ In another letter to the magazine, a young mother wrote that she was 'confined to the home for most of the time and [felt] the need for some stimulating and educational programs. ${ }^{71}$ Jenkins worked hard on the program, remarking on air that the 'broadcasting for half an hour is only a very tiny part of the job-so when I say good-bye to you all, I whip upstairs and get really busy'. ${ }^{72}$ Her radio voice was often praised. She was described by the News in March 1954 as a presenter 'who has delighted listeners all over Australia with her natural "smiling" voice'. ${ }^{73}$

Jenkins's popularity and professionalism were recognised during the 1954 royal tour of Queen Elizabeth II and the Duke of Edinburgh when she was appointed as the only female commentator from the ABC. Her experience of the tour coverage demonstrated the difficulties of live radio at the time-for example, she had to curtsy to the Queen while wearing a breastplate microphone and being entangled by cords. She was a professional, however, who had trained for the royal tour by watching a film of the royal tour of Canada and commentating on it. ${ }^{74}$ Listeners reacted well to Jenkins's approach to the tour commentary. One wrote to the $A B C$ Weekly that her 'vivid descriptions of the overall scene and

68 Ibid.

69 'The Women's Session Conducted by Ida Elizabeth Jenkins', Script, 30 November 1954, National Women's Session [Box 36], SP724/1, 13/3/4, National Archives of Australia, Sydney.

70 Joy McFetridge, 'Women's Session', $A B C$ Weekly, 20 February 1954, 2.

71 N. G. Rutherford, 'Women's Session', ABC Weekly, 1 August 1953, 2.

72 'The Women's Session Conducted by Ida Elizabeth Jenkins', Script, 3 March 1952, Monday, February to April 1952 [Scripts of the Womens Session, Women's Magazine] [2.5cm; Box 12], C3224, FEBRUARY TO APRIL 1952, NAA.

73 'Thursday Women's News', News, 25 March 1954, 23.

74 Ibid. 
quickness to note small human incidents have, in my opinion, put the male announcers to shame. ${ }^{75}$ This comment suggests that the place of women on the air was of concern to some listeners, who recognised the importance of expressing their appreciation of the work of women such as Jenkins. Elizabeth Webb described Jenkins's masterful commentary on the royal tour in a column for the Brisbane Telegraph in March 1954, observing that Jenkins 'talks to the microphone as though it were an old friend' but always ensured to keep exactly to time. Webb commended her 'complete naturalness to all females who aspire to broadcast work' and concluded that she was a good broadcaster because she 'has something to say and goes ahead and says it'. ${ }^{76}$

\section{Woman to Woman}

One major exception to the soap opera's dominance of the commercial radio in the postwar years, which again shows the exceptionalism of Western Australia, was Irene Greenwood's women's session called Woman to Woman. This program was broadcast on Perth commercial station 6PM and relayed to stations in Kalgoorlie and Northam. Greenwood intended that the program would be 'based on communications and cooperation between and for women'. ${ }^{77}$ The session was sponsored by local department store Corot \& Co., who benefited from Greenwood's facilitation of direct listener interaction with their brand through reading their letters about their 'Best Corot Buys'. ${ }^{78}$ The clothing advertisements and competitions gave the session a lighter feel than Greenwood's earlier talks for the ABC; however, it is clear that political material was still very much present on the program, albeit cloaked in a more easygoing commercial style. Although it might seem that a commercial station would be at odds with Greenwood's approach to broadcasting, commercial radio offered greater freedom for Greenwood to craft her material without needing to have every word vetted before broadcast, as was required on the ABC. Further, for the first time, Greenwood could compere her own show and control

\footnotetext{
75 Untitled article, $A B C$ Weekly, 27 February 1954, 2.

76 Elizabeth Webb, 'Your Radio Service', Telegraph, 18 March 1954, 8.

77 Kaye Murray, A Voice for Peace: The Spirit of Social Activist Irene Greenwood (1898-1992) (Perth: Kaye Murray Productions, 2005), 90.

78 See, for example, listener letters contained in QB 24, Irene Greenwood Collection, Box 12, Murdoch University Archives, Perth (hereafter MUA).
} 
what went on it - an opportunity she was not offered on the ABC. ${ }^{79}$ Finally, the program gave her the ability to reach new kinds of women, especially working-class Perth women who did not usually listen to the more patrician national broadcaster.

Jeannine Baker has shown that Greenwood drew upon her experience of feminist broadcasting in the development of her program, and that she especially sought to integrate her audience into the program by eliciting their opinions on a range of often controversial topics. ${ }^{80}$ She has argued that Woman to Woman's 'difference was marked not only by the foregrounding of non-domestic and political topics, but also by the way it paid attention to its audience'. ${ }^{81}$ It is correct that Greenwood used the greater flexibility of commercial radio to craft a program that spread her message of feminism and peace. However, Woman to Woman was in fact an attempt to prolong the tenure of this type of talk-based women's session, rather than a 'new kind of women's program' that challenged the status quo of domestic-focused women's sessions. ${ }^{82}$ Greenwood claimed that she had left the $\mathrm{ABC}$ to host the program because of her concern over listener research figures, which revealed a high percentage of women who primarily listened to serials, and she believed that she was providing 'A-class material' to women listeners of B-Class stations. ${ }^{83}$ Like King and Jenkins, Greenwood was concerned that women's sessions were being replaced by serial dramas, especially on commercial radio. Woman to Woman was less a new challenge to the domestic focus of women's programs in this era than an attempt to restore a format that was decreasing in popularity, and should, therefore, be seen within a longer tradition of engaged women's radio programming.

Woman to Woman commenced in April 1948 and was broadcast in the afternoons from $2 \mathrm{pm}$ until $2.30 \mathrm{pm}$. The schedule was same each week, which meant that listeners knew what to expect. Mondays featured a guest of the week, usually a notable woman leader in some capacity. On Tuesdays, Greenwood discussed her 'Woman of the Week', whom she chose as a notable woman leader from anywhere in the world. On Wednesday she gave book reviews, and on Thursday she read out

79 Jeannine Baker, 'Woman to Woman: Australian Feminists' Embrace of Radio Broadcasting, 1930s-1950', Australian Feminist Studies 31, no. 93 (2017): 299.

80 Ibid., 301.

81 Ibid., 300.

82 Ibid., 298.

83 Murray, A Voice for Peace, 90-91. 
listeners' letters that had been submitted in response to a pre-set question. Fridays featured a segment called 'Radio Roundabout' that gave details of events happening around Perth, such as plays and lectures. ${ }^{84}$

The Broadcaster reported that Greenwood planned to 'make the program Australian in spirit, cultural and humanitarian in outlook and to build it on news interest ${ }^{85}$ Listeners to Greenwood's ABC talks welcomed the new program and the leadership that she provided on major issues. One country listener wrote to the Broadcaster in May 1948 to express her views on the role that Greenwood played as a leader through her broadcasts:

She said that women alone could not do much but it took men and women together to cure the world's ills. Those are my sentiments and those of most women today who find themselves with problems that are the result of the two world wars. ${ }^{86}$

While Greenwood's listeners considered her to be a leader, she used her platform to promote other women in a range of leadership positions. The 'Guest of the Week' segment took the form of an interview with a notable personality, usually a woman, either a local or a visitor. Greenwood interviewed hundreds of women over the course of the program, from well-known figures such as actress Dinah Shearing to local activists. ${ }^{87}$

On 26 October 1953, Greenwood interviewed Nora Shea, purportedly the first Aboriginal woman employed in the Western Australian public service. ${ }^{88}$ In this interview, Shea discussed her work with the Coolbaroo League (CL), an Indigenous social club founded in 1947 that raised awareness of issues that affected the lives of Aboriginal people in Western Australia. ${ }^{89}$ Shea was involved in the CL's fundraising for Aboriginal hostels in Perth and, in her interview, she explained the importance of the

84 Irene Greenwood, 'Woman to Woman: 1st Diary', QB 24, Irene Greenwood Collection, Box 14, MUA.

85 Untitled article, Broadcaster, 24 April 1948, 11.

86 'Country Mouse', 'New Women's Session', Broadcaster, 8 May 1948, 17.

87 'Irene Greenwood's "Woman to Woman" Session. Stations 6 PM - 6 AM Daily at 2 p.m.', 21 December 1953, QB 24, Irene Greenwood Collection, Box 72, MUA; 'Woman to Woman', Script, 1 May 1950, QB 24, Irene Greenwood Collection, Box 25b, MUA.

88 'Irene Greenwood's "Woman to Woman" Session. Stations 6 PM - 6 AM Daily at 2 p.m.', 26 October 1953, QB 24, Irene Greenwood Collection, Box 72, MUA.

89 'Coolbaroo League', Kaartdijin Noongar - Noongar Knowledge, www.noongarculture.org.au/ coolbaroo-league/, accessed 22 November 2017. 
initiative for the lives of many young Aboriginal people. She described how many young men and women had to refuse 'apprenticeships and very good jobs in Perth' due to 'lack of suitable accommodation':

If boys and girls both had a hostel near Perth from where they could go to their respectful trades and places of employment, it would give all who occupied them a great chance and I am sure the hostels would prove their worth, and they would show, as many have shown already just what our people can do given the chance. ${ }^{90}$

Greenwood's interview with Shea generated considerable publicity. Woman's Day picked up the story and interviewed Shea about her life and her work with the CL in September 1956, and featured a photograph of her in the studio with Greenwood. ${ }^{11}$ Few Aboriginal woman had the chance to speak on radio, and it should be emphasised that Shea's ability to do so was due, in large part, to her respectability as a gainfully employed public servant. Shea used the opportunity to advocate for greater support for young Aboriginal people to achieve their potential, and to highlight to a predominantly white audience the work that Aboriginal people themselves were doing through organisations such as the CL.

Woman to Woman presented a coherent and usually unchallenged message to its listeners-it was not a forum for free debate but a tool for Greenwood to promote her messages to an audience of working-class women. As such, she selected guests who fit with her feminist message and often drafted outlines of the interview beforehand, thus attempting to control the topics discussed and to create a 'consensus dialogue.' ${ }^{22}$ She took a similar approach in the 'Mailbag to Microphone' segment. Greenwood chose the topic that listeners responded to then selected letters that were sent to an adjudicator who chose the winner and runner-up. These letters were then read over the air. The adjudicators were generally professional, middle-class women who were 'receptive to the ideology of the women's movement' - often Greenwood's friends. ${ }^{93}$ Sometimes these women also entered letters themselves. For example, Women's Service Guilds president Isabel Johnson won in April 1951 for her letter about the qualities required of women in parliament. Greenwood was an

90 Ibid.

91 Hugh Schmidt, 'The Half-Caste Crusader', Woman's Day, 17 September 1956, 44.

92 John Andrew Richardson, 'The Limits of Authorship: The Radio Broadcasts of Irene Greenwood, 1936-1954' (Honours thesis, Murdoch University, 1988), 63-65.

93 Ibid., 66. 
active member of the WSG and the adjudicator, Ida Swift, was Johnson's neighbour. ${ }^{94}$ In this way, even the segments of the show that purported to present the opinions of other women were structured to reinforce Greenwood's vision. She created this consensus dialogue because of her sincere belief in her role to educate the public through her broadcasts. ${ }^{95}$ The control she had over the message of the program was one of ways in which she exercised leadership over these issues. To combat what she saw as the increasingly dominant message that a woman's place was in the home, Greenwood believed that she needed to enter the home with her own consistent message that women's contribution to the public sphere was crucial for the development of postwar society.

Woman to Woman needed to present a clear and coherent message that emphasised the capacity of women to contribute to society and culture on equal terms with men. At a time when that message was being undermined by an emphasis on domesticity, the program pointed to the thousands of women across the world who were working to make the world a better place. This was especially the case in the 'Woman of the Week' segment, which was the successor to Greenwood's long-running $\mathrm{ABC}$ talks on Women in the International News, and were structured in a similar way. She identified notable women from her reading, or women who were in the news or connected to an important date. In March 1949, for example, she discussed the appointment of Isobel McCorkindale, who had long been an organiser in the Women's Christian Temperance Union and had lived and worked all over Australia, as one of Australia's representatives to the United Nations Status of Women Commission. Greenwood emphasised McCorkindale's outstanding qualifications, including her extensive world travel, her lecturing and writing, and her long involvement with many journals. She argued that these attributes would enable her to make an outstanding contribution to the project of bringing 'women up to that status where they have the same democratic rights as men enjoy as citizens, and workers' in all nations of the world. ${ }^{96}$

Greenwood used her sessions to promote the visibility of women she knew and respected. For example, she broadcast a tribute to feminist Linda Littlejohn following her death in March 1949. ${ }^{97}$ After providing a general

94 Ibid., 67.

95 Ibid., 69.

96 'Woman to Woman', Script, 1 March 1949, QB 24, Irene Greenwood Collection, Box 14, MUA.

97 'Woman to Woman', Script, 29 March 1949, QB 24, Irene Greenwood Collection, Box 14, MUA. 
biography, she told her listeners about her own personal memories of Littlejohn. The impact that Littlejohn had had on Greenwood's own broadcasting career was made clear. When Littlejohn ran the women's session on 2UE in Sydney in the 1930s, Greenwood would deputise for her when she was out of town. As a result, Greenwood found herself 'doing broadcasting, debating, and speaking more and more on public platforms'.$^{98}$ She mused that 'no other woman had so great an influence upon me, for she literally shaped my ideas through reading the books which she generously gave to me'. ${ }^{99}$ Littlejohn's status as a leader-a persuasive speaker, organiser, mentor and broadcaster-is apparent in this talk. Greenwood also makes clear the extent to which broadcasting as a tool of women's leadership was pioneered and then shared with others by Littlejohn. This example shows that the development of radio as a key platform from which women could exercise leadership on the big issues of the day was very much the result of the drive of individual women who recognised the power of the medium and especially its ability to reach a large audience of women.

At the beginning of each new year, Greenwood used several sessions to discuss 'women in the news, and the news they affected' throughout the previous 12 months. In January 1949, she looked back on 1948 and discussed athlete Shirley Strickland's success at the London Olympics, as well as the relative backwardness of Australia regarding women's equality. She noted that 'returning travellers tell us again and again that in Britain, and in Europe, women have succeeded in doing anything they want to do without limitations'. ${ }^{100}$ Scandinavian countries were particularly advanced in this regard. By contrast, any Australian woman in an 'unusual post' was so rare that she became news. ${ }^{101}$ Greenwood's extensive knowledge of the fight for women's equality in different parts of the world was an important aspect of her leadership on that issue in Australia. By comparing the situation in Australia to like-minded nations and informing her listeners about the gains made by women in the United States and Europe, she sought to fuel in her listeners not only a recognition that greater gender equality was possible, but also anger that Australia was lagging behind.

98 Ibid.

99 Ibid.

100 'Woman to Woman', Script, 11 January 1949, QB 24, Irene Greenwood Collection, Box 14, MUA.

101 Ibid. 
In this way, she tried to develop a feminist consciousness among her listeners, especially among the more working-class audience that she was capturing through her commercial program.

Greenwood retired from broadcasting in March 1954 after two decades of being a leading radio voice for the peace movement and women's equality in Western Australia. The Broadcaster reported that, during her six years of hosting Woman to Woman, she had interviewed over 300 'Guests of the Week', profiled thousands of women as part of the 'Woman of the Week' segment and interviewed another 300 women as part of the 'Radio Roundabout' segment. ${ }^{102}$ The letters she received from listeners when Woman to Woman went off the air indicate that her approach was appreciated. One Kalgoorlie woman wrote that Greenwood had 'brought the woman of the outback to the city', while a British migrant in Perth claimed that she had come 'to know much about Australia and its people' through the session and was now happily settled. ${ }^{103}$ Although not as longstanding as King's session, Woman to Woman demonstrated that commercial radio could also offer feminist programming and that the presence of clothing advertisements did not necessarily preclude discussions of women's equality.

\section{Conclusion}

During the postwar years, soap operas were especially lucrative for commercial stations, as they leveraged their significant female audience to attract advertisers to sponsor increasing numbers of dramas. The rising popularity of serials alarmed those who believed that radio's most important role was as a medium that fostered an engaged citizenry-especially one that included women citizens. Women such as Ida Elizabeth Jenkins, Catherine King and Irene Greenwood viewed women's programming as a way to bring the public sphere to housewives and housewives into the public sphere. They built their own profiles as leading women through the medium, but this was something that could not continue if audiences

102 'Irene Greenwood Says Farewell to Radio', Broadcaster, 3 April 1954, 5.

103 Joyce Hardey to Irene Greenwood, 20 March 1954, QB 24, Irene Greenwood Collection, Box 72, MUA; Beryl Harper to Irene Greenwood, 18 March 1954, QB 24, Irene Greenwood Collection, Box 72 , MUA. 
dwindled. Nevertheless, these women continued to view broadcasting, and especially women's sessions, as a key platform for the advancement of women's equality in the postwar era.

Why did talk-based women's sessions decline in this period? First, it should be remembered that women's sessions were a type of programming that was developed in the late 1920s and early 1930s; therefore, they were a product of an earlier generation and their appeal to younger listeners was clearly waning in comparison with soap operas. Women's sessions were most popular in the crisis years of the 1930s and 1940s, and their ethos of social justice, intellectual engagement and active citizenship may not have been as appealing as prosperity grew in the postwar era. Western Australia provides an exception to the general pattern, as talk-based women's sessions thrived there until the 1960s, as seen in the examples of King and Greenwood. Second, soap operas were powerful dramatisations of the complexities, frustrations and joys of women's lives, while also being well produced and entertaining. Thus, they were both a form of escapism from boredom and a validation of women's experiences. As the next chapter shows, in Australia's regional and rural areas, women's radio played a key role in strengthening and supporting local communities for several decades. 
This text is taken from Sound Citizens: Australian Women Broadcasters Claim their Voice, 1923-1956, by Catherine Fisher, published 2021 by ANU Press, The Australian National University, Canberra, Australia.

doi.org/10.22459/SC.2021.05 